Jurnal Manajemen dan Bisnis Jayakarta, Volume 1, No. 2, Januari 2020

\title{
PENGARUH MODAL SAHAM DAN UTANG TERHADAP PROFITABILITAS PADA PERUSAHAAN PERDAGANGAN ECERAN YANG TERDAFTAR DI BEI PERIODE 2015-2017
}

\author{
Violita Kusdiartini ${ }^{1}$, Saprudin ${ }^{2}$ \\ Sekolah Tinggi Ilmu Ekonomi Jayakarta \\ Jakarta, Indonesia \\ violitadiarti10@gmail.com, saprudinmaksudi@gmail.com
}

\begin{abstract}
ABSTRAK
Perdagangan eceran sebagai bagian dari kegiatan perdagangan besar, memiliki peran yang tinggi dalam penyaluran barang dan jasa didalam aktivitas ekonomi. Tanpa didukung oleh usaha perdagangan besar dan eceran maka kegiatan penyaluran barang menjadi kurang efektif dan efisien. Dengan demikian betapa pentingnya peran perusahaan perdagangan eceran ini.

Penelitian ini memiliki tujuan untuk mengetahui apakah terdapat pengaruh signifikan dari Modal Saham dan Utang terhadap Profitabilitas pada perusahaan perdagangan eceran yang terdaftar di Bursa Efek Indonesia (BEI). Sampel yang digunakan adalah sebanyak 5 perusahaan yang terdaftar di BEI selamat tahun 2015-2017. Penelitian ini menggunakan analisis regresi linier berganda dengan bantuan software SPSS for Windows 24.0.

Hasil penelitian ini diperoleh bahwa Modal Saham (Rasio Modal / Total Aset) mempunyai pengaruh signifikan terhadap Profitabilitas (Net Profit Margin), sedangkan Utang (Debt To Equity Ratio) tidak berpengaruh signifikan terhadap Profitabilitas (Net Profit Margin). Namun secara simultan Modal Saham dan Utang berpengaruh signifikan terhadap Profitabilitas (Net Profit Margin) pada perusahaan, maka manajemen perlu lebih memperhatikan kekuatan modal serta posisi utang yang dimiliki.
\end{abstract}

Kata Kunci: Modal Saham, Utang, Profitabilitas

\section{PENDAHULUAN}

Perkembangan retail atau
pasar eceran yang begitu pesat,
berdampak semakin tingginya
persaingan memperebutkan pangsa
pasar pada dunia usaha saat ini, terbukti
dengan semakin banyaknya perusahaan-
perusahaan baru yang didirikan di
Indonesia. Ini menimbulkan suatu
persaingan yang menuntut setiap
perusahaan untuk tetap bertahan agar
perusahaaan tersebut dapat berkembang,
ditambah lagi dengan mulai maraknya
penjualan via online. Salah satu aspek
penting yang harus diperhatikan adalah
Investor. Investor mempunyai tujuan
utama dalam menanamkan dananya ke

dalam perusahaan yaitu untuk mencari pendapatan.

Suatu badan usaha haruslah benar-benar memperhatikan hal yang sangat fundamental bagi perusahaannya yaitu faktor permodalan. Agar dapat memaksimalkan produktifitasnya dalam menghadapi persaingan, perusahaan harus memberikan perhatian khusus dalam penggunaan dananya dari berbagai sumber yang ada. Penyediaan dana dapat berasal dari sumber internal perusahaan yaitu laba yang ditahan dan dari sumber eksternal perusahaan yang meliputi modal saham tambahan, utang jangka panjang, maupun utang jangka pendek. Dalam kondisi tertentu 
Jurnal Manajemen dan Bisnis Jayakarta, Volume 1, No. 2, Januari 2020

perusahaan dapat memenuhi kebutuhan dananya dengan menggunakan sumber yang berasal dari dalam, namun karena adanya pertumbuhan perusahaan atau suatu kondisi, maka kebutuhan dana akan semakin besar, sehingga dalam memenuhi kebutuhan dana tersebut, perusahaan harus mencari sumber dana yang berasal dari luar perusahaan yaitu utang.

\section{Adapun profitabilitas} menggambarkan kemampuan suatu perusahaan dalam menghasilkan laba melalui semua kemampuan dan sumber daya yang ada seperti kegiatan penjualan, kas, modal, jumlah karyawan, jumlah cabang maupun unit usaha dan lain sebagainya. Sementara itu rasio profitabilitas dapat mengukur efektivitas kinerja manajemen secara keseluruhan yang ditunjukan dengan besar kecilnya tingkat keuntungan yang diperoleh dalam hubunganya dengan penjualan maupun investasi.

Salah satu transaksi yang terjadi di Indonesia, Perseroan Terbatas Indomobil Sukses International Tbk (IMAS) menambah modal anak usahanya, Perseroan Terbatas IMG Sejahtera Langgeng (IMGSL). Perseroan melaksanakan haknya atas aksi penerbitan saham baru IMGSL. Penambahan modal membuat modal dasar IMGSL meningkat dari Rp600 miliar menjadi Rp 1 triliun. Sedangkan modal ditempatkan dan disetor naik dari Rp584,96 miliar menjadi Rp624,96 miliar. Presiden Direktur Indomobil Jusak Kertowidjojo mengatakan, penambahan modal dilakukan dengan metode penerbitan saham baru sebanyak 39.996 unit. "Setiap saham baru seharga Rp1 juta," ujarnya dalam keterangan resminya di Jakarta, Selasa (3/9). Total saham kepemilikan saham perseroan di IMGSL setelah penerbitan saham baru bertambah dari 584.897 menjadi 624.893 saham. Sedangkan sisanya dimiliki Perseroan Terbatas Tritunggal Intipermata sebanyak 69 saham. Penguatan struktur permodalan, menurut dia, dapat meningkatkan kemampuan perseroan untuk memperoleh keuntungan, sehingga berdampak positif terhadap laporan keuangan konsolidasi perseroan. (http://investor.id, 4 September 2013).

Presiden Direktur Garuda Metalindo Ervin Wijaya mengatakan, akuisisi ini merupakan kerja strategis perseroan untuk mendapatkan jaminan kualitas dan suplai bahan dasar kawat baja dan untuk melakukan efisiensi biaya pembelian bahan dasar. Saat ini kontribusi MPF pada perusahaan holding sekitar $20 \%$ dengan penjualan berkisar Rp200 miliar. Perseroan menyiapkan setidaknya Rp350 miliar belanja modal (capital expenditure/capex) hingga pertengahan tahun depan. "Tahun ini nilainya di bawah Rp300 miliar," kata dia. Pihaknya juga berencana menambah mesin dengan total 4 pembelian US\$ 3-4 juta dalam beberapa tahun ke depan. Adapun sumber dana capex berasal dari pinjaman perbankan sekitar Rp200 miliar dan selebihnya akan diambil dari kas internal perusahaan. Lebih lanjut Ervin mengatakan, perusahaan manufaktir komponen kendaraan bermotor akan terus melakukan ekspansi ekspor, seperti Thailand dan India. (http://investor.id, 9 Mei 2017)

Kinerja Perseroan Terbatas Astra International Tbk (ASII) di sembilan bulan pertama tahun ini kurang menggembirakan. Di kuartal III-2015, laba bersih perseroan turun $17 \%$ dari Rp14,499 triliun menjadi Rp11,997 triliun. Laba bersih per saham juga turun dari Rp358 ke Rp296 per saham. Prijono menjelaskan, 5 Grup Astra menghadapi penurunan konsumsi domestik, persaingan di pasar mobil, pelemahan harga komoditas dan penurunan kualitas 
Jurnal Manajemen dan Bisnis Jayakarta, Volume 1, No. 2, Januari 2020

kredit korporasi dalam sembilan bulan pertama tahun ini, sehingga kontribusi dari seluruh segmen bisnis menurun kecuali alat berat dan pertambangan. Meski demikian, ekuitas yang diatribusikan kepada pemilik entitas induk masih naik $5 \%$ menjadi Rp100,313 triliun di kuartal III-2015 dari Rp95,494 triliun di kuartal III-2014. Nilai aset bersih juga naik $5 \%$ dari Rp2,359 triliun ke Rp2,478 triliun. Posisi utang bersih secara keseluruhan, di luar anak perusahaan jasa keuangan, mencapai Rp283 miliar pada 30 September 2015 dibandingkan dengan utang bersih sebesar Rp3,3 triliun pada akhir tahun 2014, karena penerimaan modal kerja yang kuat.(https://finance.detik.com, 15 Oktober 2015)

Maka dari itu manajemen perusahaan harus dapat mengambil keputusan dan kebijakan yang tepat dalam hal penggunaan dana yang berasal dari luar perusahaan yaitu utang. Agar perusahaan dapat tetap berada dalam keadaan menguntungkan. Di Indonesia layanan jasa sub-sektor perdagangan eceran telah dilakukan oleh perusahaan. Seperti halnya negara berkembang lainnya, pengembangan produksi dan modernisasi pelayanan jasa atas infrastruktur perdagangan eceran menjadi faktor penting dalam pembangunan ekonomi secara umum di Indonesia.

Penelitian ini dilakukan pada perusahaan Perdagangan Eceran yang terdaftar di Bursa Efek Indonesia periode 2015-2017.

\section{LITERATUR}

Menurut Rudianto (2018: 227235) modal saham merupakan jenis modal yang hanya terdapat dalam perusahaan yang berbentuk Perseroan Terbatas (PT) yang diperoleh dengan cara menerbitkan dan menempatkan saham-saham tersebut kepada pihak tertentu atau kepada masyarakat umum. Tingkat kepemilikan pemegang saham terhadap perusahaan tergantung seberapa besar bagian saham yang dikuasainnya.

Adapun Klasifikasi saham menurut Sentosa Sembiring (2012: 122), dalam bukunya yang berjudul Hukum Perusahaan yaitu:

a. Saham Biasa (Common Stock)

b. Saham Preferen (Preferred Stock) atau Saham Prioritas

Menurut Rudianto (2018: 194), Utang adalah kewajiban perusahaan untuk membayar sejumlah uang/ jasa/ barang di masa mendatang kepada pihak lain akibat transaksi yang dilakukan di masa lalu. Adapun Utang menurut Herry (2016: 294) adalah kewajiban yang diperkirakan akan dibayar dengan menggunakan asset lancar atau menciptakan kewajiban lancar lainnya dan harus segera di lunasi dalam jangka waktu kurang dari satu tahun.

Utang atau kewajiban yang dicatat dalam laporan keuangan tidak harus berasal dari utang atau kewajiban yang sah menurut aturan hukum saja, tetapi utang atau kewajiban yang timbul karena tujuan tertentu atau untuk alasan moral atau etika juga harus dicatat ke dalam laporan keuangan perusahaan (Rudianto, 2018: 191). Berdasarkan jangka waktu pelunasan atau penyelesaian utang atau kewajiban perusahaan dapat dibedakan menjadi dua, yaitu utang jangka pendek (lancar) dan utang jangka panjang (tidak lancar).

Klasifikasi utang menurut Menurut Irham Fahmi (2014:151) dibagi menjadi dua macam, yaitu:

1. Utang Jangka Pendek

Utang Jangka Pendek, yaitu utang atau kewajiban yang harus dilunasi dalam tempo satu tahun. Kadang kala perusahaan meminjam 
Jurnal Manajemen dan Bisnis Jayakarta, Volume 1, No. 2, Januari 2020

uang dalam jangka pendek untuk kegiatan operasi perusahaan yang biasa disebut dengan hutang (kewajiban) jangka pendek atau lancar.

Kategori umum yang termasuk dalam utang lancar atau utang jangka pendek menurut Irham Fahmi (2015:163) adalah sebagai berikut:
a. Utang Payable)
(Account
b. Utang Wesel atau Promes
c. Beban yang Masih harus Dibayar (Accrual liabilities)
d. Utang Jangka Panjang yang Sudah Jatuh Tempo
e. Utang Deviden
f. Utang Deposit Pelanggan

2. Utang Jangka Panjang

Utang Jangka Panjang yaitu utang yang jatuh temponya lebih dari satu tahun atau satu periode akuntansi. Karena itu penggunaan dana utang jangka panjang ini dipakai untuk kebutuhan jangka panjang, seperti pembangunan pabrik, pembelian tanah, gedung, dan sebagainya, dipenuhi oleh persyaratan sebagai berikut:

a. Jatuh temponya dapat terjadi dalam 1,5 tahun atau 2 tahun, 5 tahun atau lebih dari 12 bulan

b. utang jangka panjang biasanya timbul karena adanya kebutuhan dana untuk pembelian tambahan aktiva tetap,

c. menaikkan jumlah modal kerja permanen, membeli perusahaan lain atau mungkin juga untuk melunasi utang-utang yang lain.

Gina Gania (2013: 466) menyatakan kewajiban sebagai kewajiban saat ini yang akan diselesaikan melalui arus keluar sumber daya yang mengiringi manfaat ekonomi.
Definisi hutang menurut kerangka dasar pengukuran dan pengungkapan laporan keuangan (KDP2LK) dalam Dwi Martani, et. al. (2015:5) adalah sebagai berikut: "Liabilitas adalah utang entitas masa kini yang timbul dari peristiwa masa lalu, penyelesaiannya diharapkan mengakibatkan arus keluar dari sumber daya entitas yang mengandung manfaat ekonomi.

Berdasarkan definisi di atas dapat disimpulkan utang adalah kewajiban saat ini yang dimiliki oleh perusahaan yang timbul dari peristiwa masa lalu yang penyelesaiannya melalui arus keluar dari sumber daya entitas yang mengandung manfaat ekonomi.

Definisi profitabilitas menurut Munawir (2014: 33), Rentabilitas atau profitability adalah menunjukkan kemampuan perusahaan untuk menghasilkan laba selama periode tertentu. Rentabilitas suatu perusahaan diukur dengan kesuksesan perusahaan dan kemampuan menggunakan aktivanya secara produktif, dengan demikian rentabilitas suatu perusahaan dapat diketahui dengan memperbandingkan antara laba yang diperoleh dalam suatu periode dengan jumlah aktiva atau jumlah modal perusahaan tersebut.

Menurut Irham Fahmi (2014: 79) pengertian rasio profitabilitas adalah rasio ini mengukur efektivitas manajemen secara keseluruhan yang ditujukan oleh besar kecilnya tingkat keuntungan yang diperoleh dalam hubungannya dengan penjualan maupun investasi Berdasarkan definisi dari berbagai sumber di atas dapat diketahui bahwa rasio profitabilitas merupakan rasio yang dapat menunjukkan keberhasilan perusahaan dalam menghasilkan keuntungan dan dapat digunakan oleh perusahaan dalam 
Jurnal Manajemen dan Bisnis Jayakarta, Volume 1, No. 2, Januari 2020

menilai tingkat pengembalian investasi dan penjualan berdasarkan dari jumlah laba yang diperoleh perusahaan. Semakin baik rasio profitabilitas maka semakin baik menggambarkan kemampuan tingginya perolehan keuntungan perusahaan.

Sedangkan menurut Kasmir (2016:196), Rasio profitabilitas merupakan rasio untuk menilai kemampuan perusahaan dalam mencari keuntungan. Rasio ini dapat juga memberikan ukuran tingkat efektifitas manajemen suatu perusahaan. Hal ini ditunjukkan oleh adanya laba yang dihasilkan dari penjuaan dan pendapatan investasi. Inti dari penggunaan rasio ini adalah untuk menunjukkan tingkat efisiensi perusahaan.

Dari definisi-definisi tersebut di atas, dapat disimpulkan bahwa rasio profitabilitas adalah rasio yang digunakan untuk mengukur kemampuan dan keberhasilan perusahaan dalam memperoleh laba yang hubungannya dengan penjualan, aset maupun investasi.

Rasio profitabilitas memiliki tujuan dan manfaat tidak hanya bagi pihak internal, tetapi juga memiliki manfaat bagi pihak ekternal atau diluar perusahaan, terutama pihak-pihak yang memiliki kepentingan dengan perusahaan.

Tujuan penggunaan rasio profitabilitas menurut Kasmir (2016:197), adalah:

1. Untuk mengukur atau menghitung laba yang diperoleh perusahaan dalam satu periode tertentu.

2. Untuk menilai posisi laba Perusahaan tahun sebelumnya dengan tahun sekarang.

3. Untuk menilai perkembangan laba dari waktu ke waktu.

4. Untuk menilai besarnya laba bersih sesudah pajak dengan modal sendiri.
5. Untuk mengukur produktivitas seluruh dana perusahaan yang digunakan baik modal pinjaman maupun modal sendiri.

6. Untuk mengukur produktivitas dari seluruh dana perusahaan yang digunakan baik modal sendiri.

Manfaat yang diperoleh dari rasio profitabilitas menurut Kasmir (2016:197), yaitu:

1. Mengetahui besarnya tingkat laba yang diperoleh perusahaan dalam satu periode.

2. Mengetahui posisi laba perusahaan tahun sebelumnya dengan tahun sekarang.

3. Mengetahui perkembangan laba dari waktu ke waktu.

4. Mengetahui besarnya laba bersih sesudah pajak dengan modal sendiri.

5. Mengetahui produktivitas dari seluruh dana perusahaan yang digunakan baik modal pinjaman maupun modal sendiri.

Menurut Fred Weston dalam (Kasmir, 2016: 128) menyebutkan bahwa rasio likuiditas (liquidity ratio) merupakan rasio yang menggambarkan kemampuan perusahaan dalam memenuhi kewajiban (utang) jangka pendek. Artinya apabila perusahaan ditagih, perusahaan akan mampu untuk memenuhi/ membayar utang tersebut terutama utang yang sudah jatuh tempo. Dengan kata lain, rasio likuiditas berfungsi untuk menunjukkan atau mengukur kemampuan perusahaan dalam memenuhi kewajibannya yang sudah jatuh tempo, baik kewajiban kepada pihak luar perusahaan (likuiditas badan usaha) maupun di dalam perusahaan (likuiditas perusahaan).

Adapun Lailan Paradiba (2015: 120) mengatakan bahwa pengertian laba adalah item laporan keuangan mendasar dan penting yang memiliki 
Jurnal Manajemen dan Bisnis Jayakarta, Volume 1, No. 2, Januari 2020

berbagai kegunaan dalam berbagai konteks.

Menurut Walter Harrison (2013:13) laba terdiri dari empat jenis yaitu:

1. Laba kotor yang disebut juga margin kotor (gross margin) merupakan selisih antara penjualan dan harga pokok penjualan.

2. Laba operasi merupakan selisih antara penjualan dengan seluruh biaya dan beban operasi. Laba operasi biasanya tidak mencakup biaya modal (bunga) dan pajak.

3. Laba sebelum pajak merupakan laba dari operasi berjalan sebelum cadangan untuk pajak penghasilan.
4. Laba setelah pajak merupakan laba dari bisnis perusahaan yang sedang berjalan setelah bunga dan pajak.

Dalam penelitian Tengku Putri Lindung Bulan (2015) menyatakan bahwa modal kerja berpengaruh terhadap profitabilitas. Dian maulita dan Inta Tania (2018) dalam penelitiannya juga menyatakan bahwa DER tidak berpengaruh signifikan terhadap profitabilitas.

Untuk mengetahui hubungan antara variabel independen dengan variabel dependen yang digunakan dalam penelitian ini dapat dilihat pada gambar kerangka pemikiran berikut ini:

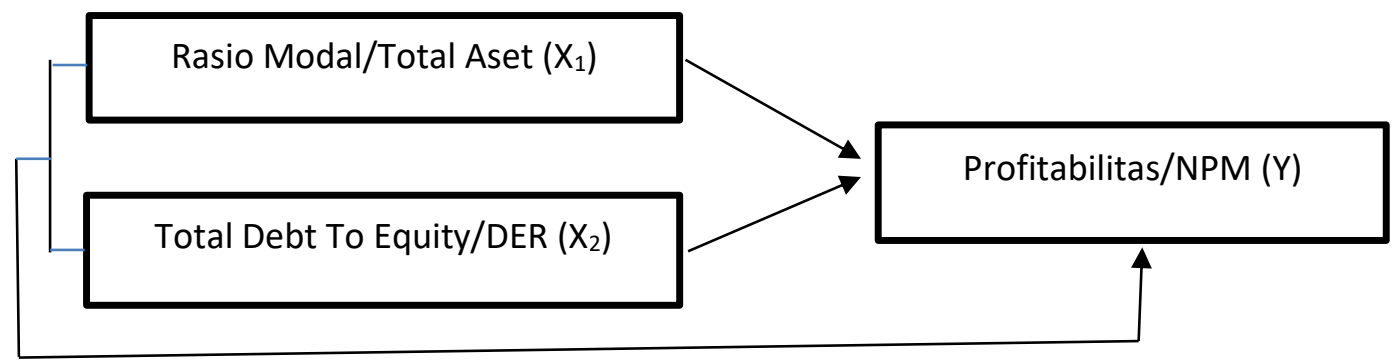

Gambar 2.1. Kerangka pemikiran

Adapun hipotesis yang peneliti rumuskan adalah sebagai berukut:

$\mathrm{H}_{1}$ : Rasio Modal / Total Aset berpengaruh terhadap Profitabilitas (NPM)

$\mathrm{H}_{2:}$ Total Debt To Equity (DER) berpengaruh terhadap Profitabilitas (NPM)

$\mathrm{H}_{3}$ : Rasio Modal / Total Aset dan Total Debt To Equity (DER) secara simultan berpengaruh terhadap Profitabilitas (NPM)

\section{METODE}

Berdasarkan sifat data yang digunakan pada penelitian ini, maka penelitian ini adalah jenis penelitian kuantitatif. Penggunaan metodologi kuantitatif sebagai prosedur penelitian yang menghasilkan data berupa angka- angka dan umumnya dianalisis dengan menggunakan statistik deskriptif atau inferensial. Dalam penelitian ini, metode penelitian kuantitatif digunakan untuk meneliti atas sampel instrumen penelitian yang diambil dengan tujuan untuk menguji hipotesis yang telah dirumuskan.

Menurut Sugiyono (2016:11), penelitian deskriftif adalah penelitian yang dilakukan untuk mengetahui nilai variabel baik satu variabel atau lebih (independent) tanpa membuat pembandingan atau hubungan dengan variabel lain. Sedangkan penelitian infrensial adalah suatu penelitian yang ditujukan untuk menguji teori dan akan mencoba menghasilkan metode ilmiah yakni status hipotesis yang berupa kesimpulan, apakah suatu hipotesis diterima atau ditolak. Penelitian 
Jurnal Manajemen dan Bisnis Jayakarta, Volume 1, No. 2, Januari 2020

infrensial merupakan penelitian yang digunakan untuk menguji hipotesis dengan menggunakan perhitungan statistika infrensial.

Adapun menurut Sofar Silaen (2018:19), Penelitian deskriftif adalah penelitian yang bertujuan untuk memberikan deskriptif, gambaran mengenai fakta-fakta, sifar-sifat, serta hubungan antar fenomena yang diteliti, termasuk hubungan kegiatan-kegiatan, sikap-sikap, pandangan-pandangan, serta proses-proses yang sedang berlangsung dan pengaruh-pengaruh dari suatu fenomena, atau untuk menentukan frekuensi distribusi suatu gejala atau frekuensi adanya hubungan tertentu antara suatu gejala dengan gejala lain.

Berdasarkan pendekatan pemakaiannya, jenis penelitian yang digunakan adalah penelitian terapan. Tujuan penelitian ini dipergunakan atau diimplementasikan dalam mengatasi masalah mengenai pengaruh modal saham dan utang terhadap profitabilitas di Perusahaan Perdagangan Eceran. Yang dinilai melalui laporan keuangan perusahaan perdagangan eceran di BEI meliputi laporan neraca, dan laporan laba/rugi selama kurun waktu 3 tahun (2015-2017).

Dalam penelitian ini yang termasuk variabel independen adalah Rasio Modal/Total Aset $\left(\mathrm{X}_{1}\right)$ dan Total Debt To Equity $\left(\mathrm{X}_{2}\right)$, sedangkan variabel dependen dalam penelitian ini adalah kinerja keuangan atau profitabilitas yang diberi simbol (Y) yang diukur mengunakan Net Profit Margin, adalah mengukur besarnya laba bersih perusahaan dibandingkan dengan penjualannya.

Populasi dalam penelitian ini adalah perusahaan Perdagangan Eceran yang terdaftar di BEI periode 20152017, dan perusahaan tersebut sudah mempublikasikan laporan-laporan keuangannya pada masyarakat umum. Sehingga masyarakat dapat melihat dengan mudah jika ingin mengetahui laporan keuangan perusahaan tersebut tanpa perlu datang langsung ke lokasi perusahaan. Untuk menentukan besarnya sampel yang diambil dari populasi dapat menggunakan rumus yang dikemukakan oleh slovin (Umi Narimawati, 2010: 38) dengan tingkat kepercayaan $90 \%$ dengan nilai $\mathrm{e}=10 \%$, atau dengan teknik lainnya.

Sampel yang diambil dalam penelitian ini adalah: PT Mitra Adi Perkasa Tbk. Matahari Putra Prima Tbk. Erajaya Swasembada Tbk. Electronic City Indonesia Tbk. Ace Hardware Indonesia Tbk.

Dalam penelitian ini, metode yang digunakan untuk mengambil sampel adalah dengan menggunakan teknik purposive sampling, adapun pada proses perhitungannya dilakukan dengan menggunakan program aplikasi komputer Statistical Package For The Sosial Science (SPSS 24.0 for Windows).

Dalam melakukan pengujian penelitian ini dilakukan dengan tiga tahapan, yaitu sebagai berikut:
a. Uji t
b. Uji-F
c. Uji Determinasi $\left(\mathrm{R}^{2}\right)$

\section{HASIL DAN PEMBAHASAN}

Data pada penelitian ini menggunakan data sekunder, yaitu berupa laporan keuangan perusahaan sub-sektor perdagangan eceran yang telah terdaftar di BEI tahun 2015-2017. Data tersebut diambil dari Bursa Efek Indonesia (BEI) dan www.idx.co.id. Dengan kriteria dalam pengambilan sampel yaitu:

1. Perusahaan subsektor perdagangan eceran yang terdaftar pada Bursa Efek Indonesia selama periode tahun 2015-2017. 
Jurnal Manajemen dan Bisnis Jayakarta, Volume 1, No. 2, Januari 2020

2. Perusahaan subsektor perdagangan eceran yang telah menerbitkan laporan keuangan neraca, laba atau rugi perusahaan selama 3 tahun pada periode tahun 2015-2017.

3. Perusahaan yang mempunyai kelengkapan data variabel (Rasio modal/ aset, Debt to equity dan Net Profit margin) yang dibutuhkan selama periode tahun 2015-2017.
Pengujian hipotesis secara parsial adalah uji statistik untuk koefisien regresi yang bertujuan untuk mengetahui pengaruh variabel independen (Rasio Modal/ Total Aset dan Debt To Equity Ratio) berpengaruh terhadap nilai Net Profit Margin.

Tabel 4.1 Tabel Uji t (parsial)

\begin{tabular}{|l|l|r|r|r|r|r|}
\hline \multicolumn{2}{|c|}{ Coefficients $^{\mathbf{a}}$} & \\
\hline \multirow{2}{*}{ Model } & \multicolumn{2}{|c|}{$\begin{array}{c}\text { Unstandardized } \\
\text { Coefficients }\end{array}$} & $\begin{array}{c}\text { Standardized } \\
\text { Coefficients }\end{array}$ & & \\
\cline { 2 - 6 } & $\mathrm{B}$ & Std. Error & Beta & \multicolumn{1}{c|}{$\mathrm{t}$} & Sig. \\
\hline 1 & (Constant) & -10.616 & 8.768 & & -1.211 & .249 \\
\cline { 2 - 6 } & $\begin{array}{l}\text { Rasio Modal } \\
\text { Sendiri }\end{array}$ & .248 & .103 & 1.080 & 2.412 & .033 \\
\cline { 2 - 6 } & $\begin{array}{l}\text { Debt to Equity } \\
\text { Rasio }\end{array}$ & .016 & .026 & .287 & .641 & .534 \\
\hline
\end{tabular}

a. Dependent Variable: Net Profit Margin

Jika nilai $t$ hitung $\left(t_{h}\right)$ lebih besar dari $\mathrm{t}$ tabel $\left(\mathrm{t}_{\alpha}\right)$ maka $\mathrm{H}_{\mathrm{o}}$ ditolak, ini berarti $\mathrm{H}_{\mathrm{a}}$ diterima. Nilai t hitung Rasio Modal/ Total Aset berdasarkan dari tabel di atas adalah $\mathbf{2 , 4 1 2}$ dari data tersebut dapat dilihat bahwa nilai $\mathrm{t}$ hitung bernilai positif maka persamaannya adalah nilai t hitung lebih besar dari nilai t tabel atau $\mathbf{2 , 4 1 2}$ $>$ 1,981 dan nilai sig < $\mathbf{0 , 0 5}$ atau $\mathbf{0 , 0 3 3}$ $<$ 0,05. Dari hasil tersebut dapat disimpulkan bahwa $\mathrm{H}_{\mathrm{o}}$ ditolak dan $\mathrm{H}_{\mathrm{a}}$ diterima. Hal ini berarti bahwa Rasio Modal/ Total Aset berpengaruh positif dan signifikan terhadap Net Profit Margin.

Apabila nilai -t hitung $\left(t_{h}\right)$ lebih kecil dari - $t$ tabel $\left(\mathrm{t}_{\alpha}\right)$ maka $\mathrm{H}_{\mathrm{o}}$ diterima, ini berarti $\mathrm{H}_{\mathrm{a}}$ ditolak. Nilai $\mathrm{t}$ hitung Debt To Equity Ratio berdasarkan dari tabel di atas adalah $(\mathbf{0 , 6 4 1 )}$. Dari data tersebut dapat dilihat bahwa nilai t hitung bernilai positif maka persamaannya adalah nilai $\mathrm{t}$ hitung lebih kecil dari nilai $\mathrm{t}$ tabel atau 0,641 $<\mathbf{1 , 9 8 1}$ dengan nilai Sig $>0,05$ atau $0,534<0,05$. Dari hasil tersebut maka dapat disimpulkan bahwa $\mathrm{H}_{\mathrm{o}}$ diterima dan $\mathrm{H}_{\mathrm{a}}$ ditolak. Hal ini berarti bahwa Debt To Equity Ratio tidak berpengaruh terhadap Net Profit Margin dengan arah positif, yaitu jika nilai DER ditingkatkan maka nilai NPM turun atau jika nilai DER turun maka nilai NPM akan naik.

Uji $F$ adalah uji statistik yang dilakukan untuk koefisien regresi yang simultan atau serentak secara bersama sama terhadap variabel $Y$.

Tabel 4.2 Hasil Uji Signifikansi Simultan

\begin{tabular}{|l|l|r|r|r|r|r|}
\hline \multicolumn{7}{|c|}{ ANOVA $^{\mathbf{a}}$} \\
\hline Model & Sum of Squares & Df & Mean Square & F & Sig. \\
\hline 1 & Regression & 337.318 & 2 & 168.659 & 12.313 & $.001^{\mathrm{b}}$ \\
\cline { 2 - 8 } & Residual & 164.369 & 12 & 13.697 & & \\
\hline
\end{tabular}


Jurnal Manajemen dan Bisnis Jayakarta, Volume 1, No. 2, Januari 2020

\begin{tabular}{|l|l|l|l|}
\hline Total & 501.686 & 14 & \\
\hline \\
\hline a. Dependent Variable: Net Profit Margin \\
b. Predictors: (Constant), Debt to Equity Rasio, Rasio Modal Sendiri \\
\hline
\end{tabular}

Nilai $\mathrm{F}$ berdasarkan tabel di atas adalah 12,313. Maka dapat dilihat bahwa nilai $\mathrm{F}$ dari tabel tersebut lebih besar dari nilai $\mathrm{F}$ tabel atau 12,313 > 3,806 dan nilai sig lebih kecil dari $\mathbf{0 , 0 5}$ atau $\mathbf{0 , 0 0 1}<\mathbf{0 , 0 5}$. Maka dapat disimpulkan bahwa kedua variabel bebas (Rasio Modal /
Total Aset dan Debt To Equity Ratio) secara simultan berpengaruh signifikan terhadap variabel $\mathrm{Net}$ Profit Margin.

Tabel 4.3 Hasil Uji Koefisien Determinasi

Rasio Modal / Total Aset terhadap NPM

\begin{tabular}{|l|c|c|c|c|}
\hline \multicolumn{5}{|c|}{ Model Summary $^{\mathbf{b}}$} \\
\hline Model & $\mathrm{R}$ & R Square & $\begin{array}{c}\text { Adjusted R } \\
\text { Square }\end{array}$ & $\begin{array}{c}\text { Std. Error of the } \\
\text { Estimate }\end{array}$ \\
\hline 1 & $.814^{\mathrm{a}}$ & .663 & .637 & 3.62855 \\
\hline \multicolumn{7}{|l|}{ a. Predictors: (Constant), Ratio Modal Asset } \\
\hline \multicolumn{4}{|l}{ b. Dependent Variable: Net Profit Margin } \\
\hline
\end{tabular}

Koefisien Determinasi adalah mengukur seberapa jauh kemampuan sebuah model dalam menerangkan variasi variabel dependen.

Berdasarkan hasil perhitungan pada analisis regresi dan diubah dalam bentuk pesentase maka $\mathrm{R}^{2}$ ( $\mathrm{R}$ square) data penelitian adalah sebesar $66,3 \%$.
Hal ini dapat diartikan bahwa Rasio Modal / Total Aset berkontribusi sebesar 66,3\% terhadap Net Profit Margin pada perusahaan perdagangan eceran. Sedangkan sisanya $(33,7 \%)$ dipengaruhi oleh variabel lain di luar model regresi ini.

Tabel 4.4 Hasil Uji Koefisien Determinasi DER terhadap NPM

\begin{tabular}{|l|c|c|c|c|}
\hline \multicolumn{5}{|c|}{ Model Summary } \\
\hline Model & $\mathrm{R}$ & R Square & $\begin{array}{c}\text { Adjusted R } \\
\text { Square }\end{array}$ & $\begin{array}{c}\text { Std. Error of the } \\
\text { Estimate }\end{array}$ \\
\hline 1 & $.717^{\mathrm{a}}$ & .514 & .477 & 4.35521 \\
\hline a. Predictors: (Constant), Debt To Equity \\
\hline \multicolumn{7}{|l}{ b. Dependent Variable: Net Profit Margin } \\
\hline
\end{tabular}

Berdasarkan hasil perhitungan pada analisis regresi diatas dan diubah dalam bentuk pesentase maka $\mathrm{R}^{2}(\mathrm{R}$ square) data penelitian adalah sebesar $51,4 \%$.

Dapat diartikan bahwa Debt To Equity Ratio berkontribusi sebesar
51,4\% terhadap Net Profit Margin pada perusahaan perdagangan eceran. Sedangkan sisanya $(48,6 \%)$ dipengaruhi oleh variabel lain di luar model regresi ini.

Tabel 4.5 Hasil Uji Koefisien Determinasi

Rasio Modal / Total Aset dan DER terhadap NPM Model Summary ${ }^{b}$ 
p-ISSN : $2715-0127$

e-ISSN : $2715-0135$

Jurnal Manajemen dan Bisnis Jayakarta, Volume 1, No. 2, Januari 2020

\begin{tabular}{|l|c|c|c|c|}
\hline Model & $\mathrm{R}$ & $\mathrm{R}$ Square & $\begin{array}{c}\text { Adjusted R } \\
\text { Square }\end{array}$ & $\begin{array}{c}\text { Std. Error of the } \\
\text { Estimate }\end{array}$ \\
\hline 1 & $.820^{\mathrm{a}}$ & .672 & .618 & 3.70100 \\
\hline a. Predictors: (Constant), Debt to Equity Rasio, Rasio Modal Sendiri \\
\hline \multicolumn{2}{|l}{ b. Dependent Variable: Net Profit Margin } \\
\hline
\end{tabular}


Jurnal Manajemen dan Bisnis Jayakarta, Volume 1, No. 2, Januari 2020

Koefisien Determinasi adalah dapat dijadikan sebagai sarana untuk mengukur seberapa jauh kemampuan sebuah model dalam menerangkan variasi variabel dependen. Berdasarkan hasil perhitungan pada analisis regresi berganda dan diubah dalam bentuk pesentase maka $\mathrm{R}^{2}$ ( $\mathrm{R}$ square) data penelitian adalah sebesar $67,2 \%$.

Dapat diartikan bahwa Rasio Modal/ Total Aset dan Debt To Equity Ratio berkontribusi sebesar 67,2\% terhadap Net Profit Margin perusahaan perdagangan eceran. Sedangkan sisanya $(32,8 \%)$ dipengaruhi oleh variabel lain di luar model regresi ini.

\section{KESIMPULAN}

Berdasarkan hasil penelitian dan pembahasan diatas maka kesimpulan yang dapat diambil adalah sebagai berikut:

1. Modal Saham (Rasio Modal/ Total Aset berpengaruh positif dan signifikan terhadap Net Profit Margin. Berdasarkan hasil perhitungan pada analisis regresi dan diubah dalam bentuk pesentase maka $\mathrm{R}^{2}$ ( $\mathrm{R}$ square) diperoleh sebesar 66,3\%. Maka dapat diartikan bahwa Rasio Modal/ Total Aset berkontribusi sebesar $66,3 \%$ terhadap Net Profit Margin Sedangkan sisanya $(33,7 \%)$ dipengaruhi oleh variabel lain di luar model regresi ini.

2. Utang (Debt To Equity Ratio) tidak berpengaruh terhadap Net Profit Margin dengan arah positif, yaitu jika nilai DER ditingkatkan maka nilai NPM turun atau jika nilai DER turun maka nilai NPM naik. Berdasarkan hasil perhitungan pada analisis regresi dan diubah dalam bentuk pesentase maka $\mathrm{R}^{2} \quad(\mathrm{R}$ square) data penelitian adalah sebesar 51,4\%. Dapat diartikan bahwa Debt To Equity Ratio

$$
\begin{aligned}
& \text { berkontribusi sebesar } 51,4 \% \\
& \text { terhadap Net Profit Margin } \\
& \text { perusahaan perdagangan eceran. } \\
& \text { Sedangkan sisanya }(48,6 \%) \\
& \text { dipengaruhi oleh variabel lain di luar } \\
& \text { model regresi ini. }
\end{aligned}
$$

3. Kedua variabel bebas (Rasio Modal/Total Aset dan Debt To Equity Ratio) secara simultan berpengaruh signifikan terhadap variabel Net Profit Margin. Berdasarkan hasil perhitungan pada analisis regresi berganda dan diubah dalam bentuk pesentase maka $R^{2}(R$ square) yang diperoleh sebesar 67,2\%. Dapat diartikan bahwa Rasio Modal/ Total Aset dan Debt To Equity Ratio berkontribusi sebesar 67,2\% terhadap Net Profit Margin perusahaan perdagangan eceran. Sedangkan sisanya $(32,8 \%)$ dipengaruhi oleh variabel lain di luar model regresi ini.

Bagi perusahaan sub-sektor perdagangan eceran diharapkan dapat memperhatikan sumber pendanaan atau utangnya. Dikarenakan utang memiliki resiko yang besar terhadap perkembangan perusahaan. Karena semakin besar utang maka semakin besar pula kewajiban untuk membayar kembali utang tersebut disertai dengan beban-beban yang disyaratkan dalam utang tersebut. Perusahaan juga perlu lebih memperhatikan tingkat profitabilitas perusahaan yang diperoleh atau kemampuan perusahaan dalam menghasilkan laba dengan cara meningkatkan volume penjualan dan menekan beban operasional, sehingga laba operasi akan meningkat.

\section{REFERENSI}

Fahmi, Irham. 2016. Manajemen Keuangan. Jakarta: Mitra Wacana Media. 
Jurnal Manajemen dan Bisnis Jayakarta, Volume 1, No. 2, Januari 2020

Gania, Gina. 2013. Definisi Utang Menurut IFRS Frame Work. Jakarta: Erlangga.

Harrison, T. Walter. 2013. Akuntansi Keuangan. Jilid 1. Edisi 8 IFRS. Jakarta: Erlangga.

Herry. 2016. Akuntansi Aktiva, Utang, Modal. Yogyakarta: Erlangga.

Kasmir. 2016. Analisis Laporan Keuangan. Jakarta: PT Raja Grafindo Persada.

Kertowidjojo, Jusak. Indomobil Tambah Modal Anak Usaha. Melalui https://investor.id/archive/indomobi l-tambah-modal-anak-usaha. (04/09/2013)

Narimawati, Umi. 2017. Stuctural Equatiion Modeling (SEM). Jakarta: Salemba Empat.

Martani, Dwi. 2015. Akuntansi Keuangan Menengah Berbasis PSAK. Jakarta: Salema Empat.

Maulita, dian dan Tania, Inta. 2018. Pengaruh Debt to Equity Ratio (DER), Debt to Asset Ratio (DAR), dan Long Term Debt to Equity Ratio (LDER) Terhadap Profitabilitas (studi Pada Perusahaan Manufaktur Sub Sektor Makanan dan Minuman Yang Terdaftar Di BEI Periode 2011-2016). Jurnal Akuntansi Vol.5 No.2 Juli 2018, 132-137.

Munawir. 2014. Analisis Laporan Keuangan. Edisi 4. Cetakan 16. Yogyakarta: Liberty.

Paradiba, Lailan. 2015. Pengaruh Laba Bersih terhadap Harga Saham pada Perusahaan Food And Baverage yang Terdaftar di BEI. Medan: Universitas Muhammadiyah Sumatra Utara.

Rudianto. 2018. Akuntansi Intermediate IFRS. Jakarta: Erlangga.

Sugiarto, Prijono. Penjualan Mobil dan Motor Merosot, Laba Group Astra
Turun 17\% Jadi 11,9T. Melaui https://finance.detik.com/bursa-danvalas/d-3057054/penjualan-mobildan-motor-merosot-laba-grup-astraturun-17-jadi-rp-119-t (29/10/2015).

Sugiyono. 2016. Metodologi Penelitian Kualitatif, Kuantitatif dan $R \& D$. Bandung: Alfabeta.

Sembiring, Sentosa. 2012. Hukum Perusahaan tentang Perusahaan Terbatas. Edisi Revisi 2016. Bandung: CV Nusantara Aulia.

Silaen, Sofar dan Widiyono. 2013. Metodologi Penelitian Sosial untuk Penulisan Skripsi dan Tesis. Jakarta: In Media.

Tengku Putri Lindung Bulan. 2015. Pengaruh Modal Kerja Terhadap Profitabilitas Pada PT. Adira Dinamika Multi Finance, Tbk. Jurnal Manajemen dan Keuangan Vol.4 No.1 Mei 2015, 305-316.

Wijaya, Ervin. Garuda Metalindo Akuisisi Sister Company 297 M. Melalui https://investor.id/archive/garudametalindo-akuisisi-sister-company-rp279-m (09/05/2017). 